\title{
EVALUASI PRODUK DAN PELAYANAN DI SALON CHRISTOPHER
}

\author{
Audrey Meiza Hazelia, Safa Tiara Putri, Sarah Diah Pitaloka Ratnaningrum \\ Program Studi Manajemen, Universitas Pembangunan Jaya, Tangerang Selatan

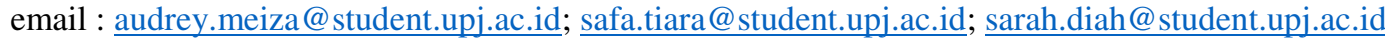

\begin{abstract}
This research aims to improve service quality and increase trust in customer satisfaction. This type of research is an evaluation of product and services at Christopher Salon using service quality. The number of samples in study amounted to 30 respondents who are customers of the salon Christopher Bintaro Jaya Xchange Mall. This type of research used in this reseach is quantitative research. Data collection in the study consisted of 2 steps namely preparation, this stage was carried out before conducting a journal research and theoretical basis. Thae second stage is observation, this stage provides questionnaries to respondents, using a simple random sampling method. Efforts to improve service quality not only have a positive impact on customers but also for The Christopher Salon.Good quality service will create loyal customers and employees will also feel valued and motivated to provide maximum performance to satisfy customers.
\end{abstract}

\section{Keywords : Service Quality,Research,Customers}

\begin{abstract}
ABSTRAK
Penelitian ini bertujuan untuk meningkatkan kualitas jasa dan meningkatkan kepercayaan terhadap kepuasaan terhadap kepuasaan pelanggan. Jenis penelitian yang dilakukan adalah evaluasi produk dan pelayanan di salon Christopher menggunakan service quality . jumlah sampel dalam penelitian ini berjumlah 30 responden yang merupakan pelanggan salon Christopher Bintaro Jaya Xchange Mall. Jenis penelitian yang digunakan dalam penelitian ini adalah penelitian kuantitatif. Pengumpulan data dalam penelitian terdiri dari 2 langkah yaitu persiapan, tahap ini dilakukan sebelum melakukan penelitian jurnal dan landasan teori. Tahap kedua adalah pengamatan, tahap ini memberikan kuesioner kepada reponden, menggunakan metode simple random sampling. Upaya untuk memperbaiki kualitas jasa tidak hanya berdampak positif bagi pelanggan saja namun juga bagi Salon Chritopher Kualitas jasa yang baik akan menciptakan pelanggan loyal dan karyawan juga akan merasa dihargai dan termotivasi untuk memberikan kinerja semaksimal mungkin untuk memuaskan pelanggan.
\end{abstract}

\section{Kata Kunci: Kualitas Jasa,Penelitian,Pelanggan}

\section{PENDAHULUAN}

Seiring dengan Globalisasi dan revolusi industri 4.0 teknologi dan informasi berkembang sangat pesat.Hal ini tentunya mempengaruhi ruang lingkup bisnis menjadi beragam dan timbulnya inovasiinovasi baru di dunia bisnis. Para pelaku bisnis baik yang sedang menjalani usaha maupun pendatang baru saling bersaing untuk mampu bertahan di Pasar dan mendapatkan profit atau laba sesuai harapan Persaingan ini menuntut perusahaan untuk dapat memuaskan pelanggannya dengan menciptakan produk atau jasa yang berkualitas sesuai dengan keinginan pelanggan. dan melakukan perubahan kearah yang lebih baik.Oleh karena itu,Salon Christopher yang berada di Bintaro Jaya X-Change Mall harus bisa meningkatkan kualitas layanannya terkait dalam hal produk maupun jasa agar dapat meningkatkan kepercayaan dan kepuasan pelanggan. Tim manajemen Salon harus peka dan cepat 
dalam merespon perkembangan bisnis yang terus berubah dan tidak tetap sehingga perlu adanya upaya evaluasi usaha.Kualitas jasa sering didefinisikan sebagai usaha pemenuhan dari keinginan pelanggan Upaya untuk memperbaiki kualitas jasa tidak hanya berdampak positif bagi pelanggan namun dapat juga meningkatkan kepuasan kerja bagi karyawan.Kualitas jasa yang baik akan menciptakan pelanggan loyal dan karyawan juga akan merasa dihargai dan termotivasi untuk memberikan kinerja semaksimal mungkin untuk memuaskan pelanggan.Berhasilnya sebuah organisasi/usaha tidak hanya ditentukan dari tim manajemen namun juga dari individu masing-masing karyawan.Dalam kualitas jasa, terdapat lima dimensi karateristik kualitas pelayanan yaitu tangibles, responsiveness, reability, assurance dan emphaty. Kelima dimensi inilah yang kemudian akan diuji menggunakan metode Service Quality atau bisa disingkat juga dengan istilah Servqual

Oleh karena itu, peneliti melakukan studi tentang "Evaluasi Produk dan Pelayanan di Salon Christopher Menggunakan Service Quality" berdasarkan lima dimensi jasa Servqual. Diharapkan dengan hasil penelitian nantinya dapat membuat Salon Christopher memaksimalkan kualitas pelayanannya. Berdasarkan latar belakang yang telah dikemukakan, maka rumusan masalah pada penelitian ini adalah mengidentifikasi atribut yang harus di evaluasi dan diperbaiki (tidak memenuhi harapan pelanggan), atribut yang perlu dipertahankan (berhasil memenuhi harapan pelanggan), dan atribut yang sudah memenuhi harapan Christopher Salon.

\section{LANDASAN TEORI}

\section{Kualitas Jasa}

Jasa merupakan setiap kegiatan, manfaat atau performance yang ditawarkan satu pihak kepada pihak lain yang bersifat intangible serta tidak menyebabkan perpindahan kepemilakan apapun yang mana dalam produksinya terikat maupun tidak dengan produk fisik. Jasa adalah setiap aktivitas atau manfaat yang ditawarkan satu pihak kepada pihak lain yang mana pada dasarnya kasat mata atau tidak berwujud, serta tidak menyebabkan kepemilikan sesuatu. Yang mana proses produksinya mungkin dan mungkin juga tidak terikat dengan produk fisik. Jasa adalah layanan yang ditawarkan oleh satu pihak kepada pihak yang lain. Adapun proses ini tidak terkait dengan produk fisik, jasa tidak berwujud, umumnya tidak menyebabkan kepemilikan dari factor produksi. Jasa adalah kegiatan ekonomi yang didalamnya terdapat sejumlah elemen (nilai atau manfaat) intangible yang berkaitan, yang melibatkan sejumlah interaksi dengan konsumen atau dengan barang-barang, namun tetap tidak menghasilkan transfer kepemilikian. Adapun emitor perubahan kondisi bisa saja muncul dan produksi layanan mungkin memiliki atau mungkin tidak memiliki koneksi dengan produk fisik. Jasa adalah proses yang terdiri dari serangkaian kegiatan berwujud yang biasanya namun tidak selalu terjadi pada interaksi antara pelanggan dengan layanan karyawan atau sumber daya fisik/barang atau penyedia system yang mana menjadi solusi untuk masalah pelanggan.

Bentuk-bentuk pelayanan tidak terlepas dari tiga macam, yaitu pelayanan dengan cara lisan, pelayanan melalui tulisan, pelayanan melalui perbuatan.

1. Pelayanan dengan cara lisan dilakukan oleh petugas-petugas dibidang hubungan masyarakat, bidang layanan informasi dan bidang-bidang lain yang tugasnya memberikan penjelasan atau keterangan kepada siapapun yang memerlukan.

2. Pelayanan melalui tulisan merupakan bentuk pelayanan yang paling menonjol dalam pelaksanaan tugas, tidak hanya dari segi jumlah tetapi juga dari segi peranannya.

3. Pelayanan melalui perbuatan

Pada perkembangannya, dalam kasus pemasaran jasa, dimensi kualitas yang paling sering digunakan sebagai acuan adalah:

1. Tangibles, atau bukti fisik yaitu kemampuan suatu perusahaan dalam menunjukkan eksistensinya pada pihak eksternal. Penampilan dan kemampuan sarana dan prasarana fisik perusahaan dan keadaan 
lingkungan sekitarnya adalah bukti nyata dari pelayanan yang diberikan oleh pemberi jasa. Ini meliputi fasilitas fisik (Gedung, Gudang, dan lainnya), teknologi (peralatan dan perlengkapan yang dipergunakan), serta penampilan pegawainya. Secara singkat dapat diartikan sebagai penampilan fasilitas fisik, peralatan, personil, dan materi komunikasi.

2. Reliability, atau keandalan yaitu kemampuan perusahaan untuk memberikan pelayanan sesuai yang dijanjikan secara akurat dan terpercaya. Harus sesuai 15 dengan harapan pelanggan berarti kinerja yang

tepat waktu, pelayanan tanpa kesalahan, sikap simpatik dan dengan akurasi tinggi. Secara singkat dapat diartikan sebagai kemampuan untuk memberikan layanan yang dijanjikan secara akurat, tepat waktu, dan dapat dipercaya.

3. Responsiveness, atau ketanggapan yaitu suatu kemauan untuk membantu dan memberikan pelayanan yang cepat (responsive) dan tepat kepada pelanggan, dengan penyampaian informasi yang jelas. Membiarkan konsumen menunggu tanpa alasan yang jelas menyebabkan persepsi yang negatif dalam kualitas pelayanan. Secara singkat dapat diartikan sebagai kemauan untuk membantu pelanggan dengan memberikan layanan yang baik dan cepat.

4. Assurance, atau jaminan dan kepastian yaitu pengetahuan, kesopan santunan, dan kemampuan para pegawai perusahaan untuk menumbuhkan rasa percaya pelanggan kepada perusahaan.

5. Empati, meliputi kemudahan dalam menjalin hubungan, komunikasi yang baik dan efektif, perhatian personal dan pemahaman atas kebutuhan individual para pelanggan.

\section{Metode Service Quality (Servqual)}

Service quality adalah suatu tingkat keunggulan yang diharapkan dimana pengendalian atas tingkat keunggulan tersebut bertujuan untuk memenuhi kebutuhan pelanggan. Kualitas pelayanan adalah tingkat keunggulan yang diharapkan dan pengendalian atas tingkat keunggulan tersebut untuk memenuhi keinginan pelanggan. Kualitas pelayanan adalah suatu sikap dari hasil perbandingan pengharapan kualitas jasa konsumen dengan kinerja perusahaan yang dirasakan konsumen, service quality adalah tingkat-tingkat ukuran atas kualitas pelayanan yang diasumsikan berhubungan dengan perkembangan harga. Berdasarkan pendapat para ahli diatas, dapat disimpulkan bahwa service quality adalah suatu tingkat ukuran akan keunggulan yang diharapkan atas kualitas pelayanan yang dihubungkan dengan perkembangan harga atau tingkat perbandingan pengharapan kualitas jasa konsumen dengan kinerja perusahaan yang dirasakan konsumen untuk menjadi pengendali perkembangan harga.

\section{METODOLOGI PENELITIAN}

Jenis penelitian yang digunakan dalam penelitian ini adalah penelitian kuantitatif. Metode penelitian kuantitatif dapat diartikan sebagai metode penelitian yang berlandaskan pada filsafat positivisme, digunakan untuk meneliti pada populasi atau sampel tertentu. Pengumpulan data dalam penelitian terdiri dari 2 langkah yaitu Persiapan, tahap ini dilakukan sebelum melakukan penelitian seperti mencari buku, jurnal dan landasan teori yang mendukung penelitian seperti teori kualitas jasa dan servqual. Melakukan studi pendahuluan dan studi literatur untuk lebih memahami topik yang diteliti dan merancang kuesioner. Isi kuisioner yang disusun mewakili 5 dimensi dalam kualitas jasa. Tahap kedua adalah Pengamatan, tahap ini memberikan kuesioner kepada responden, menggunakan metode simple random sampling. Jumlah responden dalam penelitian ini adalah 30 orang responden. Setelah melakukan penyebaran kuisoner dan mendapatkan data 30 orang v responden, maka langkah selanjutnya adalah melakukan pengolahan data dengan metode Servqual. Metode inidimulai dengan menghitung gap/selisih antara harapan pelanggan mengenai layanan jasa dengan kenyataan pelayanan yang dirasakan pelanggan. 


\section{ANALISIS DAN PEMBAHASAN}

Hasil Perhitungan Gap

Tabel 1 menunjukkan hasil perhitungan gap/selisih antara harapan dan persepsi pelanggan terhadap pelayanan jasa berdasarkan 12 atribut pernyataan kuisioner.

Tabel 1 Nilai Rata-Rata Gap 5 Terhadap Pernyataan Kualitas Layanan Jasa

\begin{tabular}{cccccc}
\hline \multirow{2}{*}{ Atribut } & \multicolumn{2}{c}{ Harapan Pelayanan } & \multicolumn{2}{c}{ Kenyataan Pelayanan } & \\
\cline { 2 - 5 } & & & & & \\
Bobot Nilai & Rata-Rata Nilai Harapan & Bobot Nilai & $\begin{array}{c}\text { Rata-Rata Nilai } \\
\text { Kenyataan }\end{array}$ & \\
\hline 1 & 129 & 4.3 & 118 & 3.93 & -3.3 \\
\hline 2 & 121 & 4.03 & 111 & 3.7 & -0.33 \\
\hline 3 & 119 & 3.96 & 112 & 3.73 & -0.23 \\
\hline 4 & 114 & 3.8 & 119 & 3.96 & 0.16 \\
\hline 5 & 124 & 4.13 & 114 & 3.8 & -0.33 \\
\hline 6 & 107 & 3.56 & 118 & 3.93 & 0.37 \\
\hline 7 & 133 & 4.43 & 116 & 3.86 & -0.57 \\
\hline 8 & 129 & 4.3 & 115 & 3.83 & -0.47 \\
\hline 9 & 133 & 4.43 & 121 & 4.03 & -0.4 \\
\hline 10 & 128 & 4.26 & 108 & 3.6 & -0.66 \\
\hline 11 & 117 & 3.9 & 110 & 3.66 & -0.24 \\
\hline 12 & 119 & 3.96 & 113 & 3.76 & -0.2 \\
\hline
\end{tabular}

Perhitungan Dimensi Kualitas Jasa Berdasarkan Servqual Gap 5

Lima dimensi dalam kualitas jasa terdiri dari reliability (keandalan), responsiveness (daya tanggap), assurance (jaminan), empathy (empati), dan tangibles (bukti fisik). Tabel 2 menunjukkan hasil perhitungan nilai rata-rata gap 5 berdasarkan lima dimensi servqual.

Tabel 2 Nilai rata-rata Gap 5 berdasarkan dimensi servqual

\begin{tabular}{ccccccc}
\hline Dimensi & Atribut & $\begin{array}{c}\text { Jumlah } \\
\text { Rata-Rata } \\
\text { Harapan }\end{array}$ & $\begin{array}{c}\text { Rata-Rata } \\
\text { Kenyataan }\end{array}$ & $\begin{array}{c}\text { Nilai } \\
\text { Harapan } \\
\text { Pelayanan }\end{array}$ & $\begin{array}{c}\text { Nilai } \\
\text { Kenyataan } \\
\text { Pelayanan }\end{array}$ & $\begin{array}{c}\text { Nilai Gap } \\
5\end{array}$ \\
\hline Reliability & 11,12 & 20.5 & 18.58 & 2.16 & 2.16 & 0 \\
\hline Responsiveness & 9,10 & 21.75 & 19.08 & 2 & 2.33 & 0,33 \\
\hline Assurance & $3,4,5$ & 32.25 & 28.75 & 3.16 & 3.3 & 0.17 \\
\hline Empathy & $6,7,8$ & 33 & 29.08 & 4.33 & 3.16 & -1.17 \\
\hline Tangibles & 1,2 & 21.66 & 19.08 & 2 & 2 & 0 \\
\hline
\end{tabular}

Dari tabel 2 dapat diketahui dimensi yang memiliki gap terbesar sampai dengan yang terkecil. Semakin besar gap yang didapat dari perhitungan gap 5 maka semakin kurang baiknya kualitas pelayanan jasa tersebut. Dan sebaliknya, semakin kecil gap yang didapat dari perhitungan gap 5 (gap tersebut nol dan positif) maka semakin baik kualitas pelayanan jasanya. Oleh karena itu, prioritas perbaikan pelayanan jasa dilakukan dari gap atau kesenjangan terbesar. Berdasarkan tabel 2 dapat dilihat bahwa dimensi kualitas jasa Responsiveness (daya tanggap) dan Tangibles (bukti fisik) Disesuaikan dengan hasil studi memiliki gap yang bernilai positif. Dimensi kualitas jasa Responsiveness memiliki nilai gap 0.33 dan dimensi kualitas jasa Tangibles memiliki nilai gap 0 . Disesuaikan dengan hasil studi Responsiveness dan Tangibles. Kedua dimensi ini yang perlu di pertahankan oleh Salon Christopher karena telah berhasil memenuhi kepuasan pelanggan. Dan dimensi kualitas 
jasa Reability (keandalan), Assurance (jaminan) disesuaikan dengan hasil studi memiliki nilai gap positif. Sedangkan Empathy (empati) Disesuaikan dengan hasil studi memiliki nilai gap yang negatif. Hal ini berarti setelah disesuaikan dengan hasil studi dimensi kualitas jasa ini sudah cukup berhasil memenuhi kepuasan pelanggan dan perlu adanya sedikit perbaikan di bagian dimensi Empathy (Empati).

Tabel 3 Urutan nilai Gap 5 dari Gap Terkecil Sampai Gap Terbesar

\begin{tabular}{ccc}
\hline Atribut & Pernyataan & Nilai Gap 5 \\
\hline 6 & Karyawan bersikap ramah & 0.37 \\
\hline 4 & Produk yang ditawarkan berkualitas baik & 0.16 \\
\hline 12 & Lokasi mudah dijangkau & -0.2 \\
\hline 9 & Karyawan melayani dengan baik & -0.4 \\
\hline 3 & Produk lengkap & -0.23 \\
\hline 11 & Produk mudah dicari & -0.24 \\
\hline 2 & Produk terususun rapih & -0.33 \\
\hline 5 & Kualitas produk sesuai harga & -0.33 \\
\hline 8 & Karyawan menyambut kedatangan pelanggan & -0.47 \\
\hline 7 & Karyawan murah senyum & -0.57 \\
\hline 10 & Saran dan keluhan ditanggapi dengan baik & -0.66 \\
\hline 1 & Tempat nyaman dan bersih & -3.3
\end{tabular}

Berdasarkan tabel 3, terdapat 2 atribut pernyataan yang bernilai gap positif (sudah memenuhi harapan konsumen) dan 10 atribut pernyataan yang bernilai gap negatif (perlu adanya evaluasi dan perbaikan). Atribut pernyataan yang bernilai positif adalah atribut nomor $6 \& 4$. Sedangkan atribut pernyataan nomor $1,2,3,5,7,8,9,10,11$, dan 12 bernilai negatif.

\section{Kesimpulan}

\section{KESIMPULAN DAN SARAN}

1. Atribut pernyataan yang bernilai negatif (perlu adanya evaluasi dan perbaikan) diantaranya adalah atribut nomor 1, 2, 3, 5, 7, 8, 9, 10,11, dan 12

2. Atribut pernyataan yang bernilai positif (sudah memenuhi harapan pelanggan dan perlu dipertahankan) diantaranya adalah 4 dan 6

3. Dimensi jasa yang sudah memenuhi harapan pelanggan adalah dimensi jasa Assurance dan Empathy

4. Dimensi jasa yang belum memenuhi harapan pelanggan (perlu adanya evaluasi dan perbaikan) adalah dimensi jasa Reliability, Responsiveness,Tangibles 


\section{References}

[1] Tannady, H., Andrea, B., Nurprihatin, F., \& Lusiani, M. (2017). Analisis Kualitas Jasa pada Maskapai Penerbangan Rute Domestik Tarif Menengah Kebawah dengan Menggunakan Metode Servqual dan Metode Importance And Performance Analysis. Prosiding SNATIF, hal. 693-699.

[2] Wilujeng, F. R., Rembulan, G. D., Andreas, D., \& Tannady, H. (2019). Meningkatkan Kepuasan Pelanggan Pada Dua Bisnis E-Commerce Terbesar di Indonesia Dengan Menggunakan Analisis Servqual dan IPA. SEMNASTEK-Seminar Nasional Sains dan Teknologi 2019, hal. 1-9.

[3] Lusiani, M., Yuirafat, A., \& Tannady, H. (2017). ANALISIS KEPUASAN PENGGUNA BPJS DAN NON BPJS TERHADAP LAYANAN RUMAH SAKIT DENGAN MODEL QUALITY FUNCTION DEPLOYMENT. Seminar Nasional Akuntansi dan Bisnis (SNAB), Fakultas Ekonomi Universitas Widyatama.

[4] Tannady, H. (2018). Psikologi Industri dan Organisasi. Yogyakarta : Penerbit Expert.

[5] Tannady, H., Nurprihatin, F., \& Hartono, H. (2018). Service quality analysis of two of the largest retail chains with minimart concept in Indonesia. Business: Theory and Practice, 19, 177-185. 